\title{
ЮРИСДИКЦІЯ СПРАВ ПРО СКАСУВАННЯ НАКАЗІВ МІНІСТЕРСТВА ЮСТИЦIї УКРАЇНИ ЩОДО СКАРГ У СФЕРІ ДЕРЖАВНОЇ РЕЄСТРАЦІЇ РЕЧОВИХ ПРАВ
}

Щодо оскарження рішень, дій чи бездіяльності 3 приводу державної реєстрації речових прав на нерухоме майно передбачена альтернативна юрисдикція: 1) суду; 2) Міністерства юстиції України (далі - Мін'юст) або його територіальних органів (залежно від змісту оскаржуваних рішень, дій, бездіяльності та суб'єктів їх учинення).

До юрисдикції Мін'юсту належить розгляд скарг на рішення: 1) державного реєстратора про державну реєстрацію прав (окрім випадків набуття такого права на підставі судового рішення та наявності судового спору щодо нерухомості); 2) а також дії (бездіяльність) територіальних органів Мін'юсту.

Накази Мін'юсту, прийняті за результатами розгляду відповідних скарг у сфері державної реєстрації речових прав (далі - накази), можуть оскаржуватися до суду, а відповідні справи - розглядатися за правилами цивільного, господарського або адміністративного судочинства.

Правильне визначення судової юрисдикції відповідної справи $є$ одним із критеріїв законності прийнятого судового рішення, яке у разі порушення правил юрисдикції підлягає обов'язковому скасуванню.

Юрисдикційні питання даної категорії справ не були предметом окремого наукового дослідження. Відповідні процесуальні кодекси містять лише загальні засади розмежування видів судової юрисдикції. Аналіз судової практики розгляду таких справ свідчить про неоднозначне вирішення судами питання щодо їх юрисдикції. Більшість юрисдикційних порушень, допущених під час розгляду цих справ, установлюється в межах касаційного провадження, що призводить до скасування судових рішень і закриття провадження у справі та значно знижує оперативність і (як наслідок) ефективність судового захисту речових прав у сфері державної реєстрації. Зазначені обставини актуалізують дослідження цих юрисдикційних питань.

Метою цієї статті є конкретизація обставин, що визначають певний вид судової юрисдикції справ щодо скасування наказів Мін’юсту, прийнятих за скаргами у сфері державної реєстрації речових прав на нерухоме майно.

Вирішуючи питання щодо виду судової юрисдикції спору про законність наказу Мін'юсту, слід виходити 3 характеру спірних правовідносин, оскільки залучення Мін'юсту (як і державного реєстратора) відповідачем не $є$ достатньою ознакою адміністративної юрисдикції. Суб'єктний критерій визначення судової юрисдикції має використовуватися у поєднанні з предметним, який дає змог віднести спір до публічно- чи приватноправового. Для цього необхідно, зокрема, з'ясовувати, у зв'язку з чим виник спір та за захистом яких прав особа звернулася до суду.

Спір має приватноправовий характер, якщо він зумовлений порушенням або загрозою порушення майнового права чи інтересу, що підлягає захисту 
в спосіб, передбачений законодавством для приватноправових відносин.

Якщо порушення своїх прав особа вбачає в наслідках рішення, дії чи бездіяльності суб'єкта владних повноважень (які вона вважає неправомірними), що призвели до виникнення, зміни чи припинення цивільних правовідносин, то визнання незаконними (протиправними) таких рішень є способом захисту цивільних прав та інтересів [1]. Участь у такому спорі Мін'юсту та державного реєстратора як співвідповідача не змінює його приватноправового характеру [2].

У межах предметного критерію оцінюється, зокрема, зміст позову.

Наприклад, Верховний Суд (далі BC) у справі № 821/669/17 [3] зазначив, що такий спосіб захисту, як поновлення скасованих записів про право власності на земельні ділянки, не породжує спір про поновлення майнових прав позивача, адже таке поновлення не пов'язане 3 виникненням або припиненням права на ці земельні ділянки, а є наслідком скасування неправомірного (як уважає позивач) наказу Мін'юсту про скасування реєстраційної діi. Вимога про поновлення реєстраційних записів не може розглядатися окремо, оскільки є наслідком визнання незаконним i скасування наказу Мін'юсту. Мін'юст у спірних правовідносинах є суб'єктом владних повноважень, щодо оскарження дій якого виник спір, що стосується публічно-правових відносин і грунтується виключно на непогодженні з управлінськими функціями Мін'юсту, тому за суб'єктним складом і характером правовідносин позов належить до адміністративної юрисдикції.

Аналогічного правового висновку дійшла Велика Палата ВС у справі № 910/8424/17 [4].

Якщо у справі підставою позову $€$ виключно порушення Мін'юстом процедури розгляду скарги, а законність фактів, що були підставою для вчинення реєстраційних дій, у справі не оспорюється, спір належить до адміністративної юрисдикції. Оскільки в справі № 804/2296/17 щодо законності наказів Мін'юсту предметом розгляду була виключно процедура розгляду скарги відповідачами та законність оскаржуваного рішення, а законність фактів, які були підставою для вчинення реєстраційних дій, у справі не оспорювалася, справа належала до адміністративної юрисдикції [5].

У справі № 826/3442/17 ВС зауважив, що спірні правовідносини виникли у зв'язку з оскарженням рішення суб'єкта владних повноважень - Мін'юсту про скасування рішень про державну реєстрацію за наслідками розгляду скарги банку на реєстраційні дії державного реєстратора - приватного нотаріуса щодо прав інших суб'єктів господарювання. ВC підкреслив, що в межах цієі адміністративної справи вирішувався лише публічно-правовий спір щодо правомірності наказу Мін'юсту. Суди мали з'ясувати, чи були дії Мін'юсту здійснені в межах повноважень, відповідно до закону та з дотриманням установленої процедури [6].

Якщо ж позивач оскаржує наказ Мін'юсту з посиланням на відсутність у іншої особи (навіть якщо така особа залучена як третя особа, яка не заявляє самостійних вимог щодо предмета спору, на боці відповідача) прав на нерухоме майно, то наявний приватноправовий спір.

Наприклад, у спорі за позовом господарського товариства до Мін'юсту про визнання протиправним i скасування наказів ВС зробив висновок про те, що позовні вимоги спрямовані на захист права користування земельними ділянками, а спір фактично виник між позивачем і третіми особами з приводу захисту цього права. Тому справа не належала до адміністративної юрисдикції [7]. Аналогічний висновок відображено у Постанові Великої Палати ВC від 29 травня 2019 р. у справі № $826 / 9341 / 17$ [8] та Постанові ВC від 03 березня 2020 р. у справі № $826 / 6166 / 17$ [9]. 
Велика Палата ВC у Постанові від 30 січня 2020 р. у справі № 826/5968/17 [10] зауважила, що спір зумовлений незгодою позивача 3 наказами Мін'юсту в частині скасування реєстраційних дій щодо державної реєстрації змін у праві власності на спірне нерухоме майно. Отже, позов заявлено на поновлення порушеного цивільного (майнового) права позивача. Спірні правовідносини виникли між учасниками справи (здебільшого між позивачем та третьою особою) у зв'язку 3 невиконанням договірних зобов'язань із реалізації прав іпотекодержателя на предмети іпотеки. Позовні вимоги призводять до вирішення питання про право власності на це нерухоме майно. Тому позов не належить до адміністративної юрисдикції. Належним відповідачем є особа, право на майно якої оспорюється та щодо якої здійснено запис у відповідному державному реєстрі. Оскарження рішень про державну реєстрацію права власності безпосередньо пов'язане із захистом цивільного права у спорі з іншою особою.

У справі № 826/5364/18 з огляду на те, що спірними $€$ рішення державних реєстраторів щодо реєстрації переходу права власності на нерухоме майно (тобто позовні вимоги заявлено для поновлення порушеного майнового права позивача), ВС дійшов висновку, що спір не $є$ публічно-правовим i не належить до адміністративної юрисдикції [11].

Аналогічна правова позиція відображена й у Постанові від 17 жовтня 2019 р. у справі № 826/13993 / 17 [12], в якій ВС зауважив, що виникнення спірних правовідносин у цій справі зумовлено незгодою позивача 3 наказом Мін'юсту щодо задоволення скарги та скасування рішення про державну реєстрацію прав та їх обтяжень. Позовні вимоги у справі заявлено на поновлення порушеного цивільного (майнового) права позивача та $є$ похідними від вирішення судом питання щодо правомірності набуття права власності на об'єкт нерухомого майна та можуть впливати на майнові права й інтереси цих осіб. Незважаючи на участь у спорі суб'єкта владних повноважень, цей спір не є публічно-правовим і не належить до адміністративної юрисдикціï. Розгляд адміністративної справи лише щодо наказу Мін'юсту, яким скасовано реєстраційні дії, може призвести до ситуації, коли реєстраційні записи у відповідному державному реєстрі не співпадатимуть 3 юридичними фактами, на підставі яких вони вчинені, та не відображатимуть реальний правовий стан. Тому спірні правовідносини є неподільними, а правова оцінка наказу Мін'юсту на предмет дотримання процедури не може превалювати над оцінкою права власності.

До схожих висновків ВС дійшов у справі № 2040/8209/18 [17], зазначивши, що позовні вимоги спрямовані на визнання права оренди земельних ділянок, тобто на поновлення порушеного цивільного (майнового) права позивача. Оскарження рішень про державну реєстрацію права користування спірними земельними ділянками є захистом прав позивача на земельні ділянки від іх порушення іншою особою, за якою зареєстровано право оренди щодо тих самих земельних ділянок. Позовні вимоги у цій справі грунтуються на вирішенні питання щодо правомірності набуття права оренди земельних ділянок і можуть впливати на майнові права та інтереси цих осіб. Тому ВС, незважаючи на участь у спорі суб'єкта владних повноважень, дійшов висновку, що цей спір не є публічно-правовим та не підлягає розгляду в порядку адміністративного судочинства. Спірні правовідносини є неподільними та правова оцінка наказу Мін'юсту на предмет дотримання процедури не може превалювати над оцінкою права оренди земельних ділянок.

У справі № 826/19534/16 [13] BC зауважив, що позивач незгодний із наказом Мін'юсту про скасування рішення про державну реєстрацію прав за результатом розгляду скарги ПАТ 


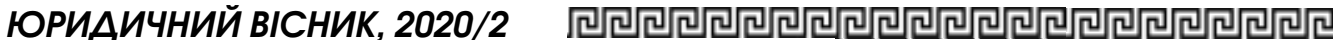

«Всеукраїнський акціонерний банк», а позовні вимоги у справі заявлено на поновлення порушеного цивільного (майнового) права позивача. Тому цей спір не є публічно-правовим і не підлягає розгляду в порядку адміністративного судочинства.

У справі № 910/7781/19 [14] Велика Палата ВС віднесла вимоги ТОВ «Колорит АГРОС» до Мін'юсту про визнання незаконним скасування наказу та зобов'язання вчинити певні дії до цивільної юрисдикції, оскільки фактично спір виник між позивачем і ТОВ «ПК «Справа» 3 приводу права користування земельними ділянками, що належали фізичним особам. Так, ТОВ «ПК «Справа» уклало 3 власниками земельних ділянок додаткові угоди до договорів про продовження строку дії договорів оренди землі, проте останньому було відмовлено у державній реєстрації права оренди у зв'язку 3 тим, що таке право вже зареєстровано за ТОВ «Колорит АГРОС». Тому цей спір є спором про право цивільне, тобто має приватноправовий характер.

У Постанові від 12 лютого 2020 р. у справі № 1840/3241/18 [15] Велика Палата ВС зазначила, що спір не є спором між учасниками публічно-правових відносин, оскільки спірне рішення відповідача про скасування державної реєстрації ухвалене за скаргою не позивача, а іншої особи. Визнання протиправним і скасування рішення про державну реєстрацію права оренди земельних ділянок за позивачем є захистом його прав на земельні ділянки від ї порушення іншою особою, за якою зареєстровано аналогічне право щодо того ж самого нерухомого майна. Позивач обгрунтував позовні вимоги наявністю в нього права оренди і відсутністю такого права у ПрАТ «Райз-Максимко». Цей спір виник між позивачем і ПрАТ «Райз-Максимко» щодо права на спірні земельні ділянки, що підлягає державній реєстрації. Тому спір про скасування зазначеного наказу Мін'юсту має розглядатися як пов'язаний із порушенням цивільних прав позивача на земельну ділянку іншою особою, за якою було зареєстровано аналогічне право на ті ж об'єкти та яка є належним відповідачем у такій справі.

У справі № 815/1446/18 [16] ВС зазначив, що реєстраційні діï, скасовані наказом Мін'юсту, стосуються реєстрації прав на будівлі та споруди, отже, даний спір не є публічно-правовим та не належить до юрисдикції адміністративних судів. Спір виник між фізичною та юридичною особами, а тому має вирішуватися в порядку цивільного судочинства.

У межах адміністративного судочинства розглянуто справу № 819/1499/17 [18] за позовом приватного нотаріусу до Мін'юсту про визнання протиправним і скасування пункту 3 наказу Мін'юсту від 30 червня 2017 р. № 2048/5. У задоволенні цього позову суд відмовив, оскільки позивач як державний реєстратор під час державної реєстрації речових прав на нерухоме майно не перевірив інформацію про наявність або відсутність уже зареєстрованих речових прав із метою недопущення одночасного існування їх подвійної державної реєстрації. 3 огляду на наявні у діях позивача порушення закону під час учинення зазначених реєстраційних дій, відповідачем правомірно застосоване до позивача як державного реєстратора тимчасове блокування доступу до відповідного державного реєстру прав.

Також у порядку адміністративного судочинства розглянуто справу за позовом державного реєстратора прав на нерухоме майно до Мін'юсту про скасування наказу Мін'юсту в частині тимчасового блокування доступу позивача до Державного реєстру речових прав на нерухоме майно строком на 12 місяців. Розглядаючи касаційну скаргу позивача на судові рішення у цій справі, ВС зауважив, що невчасне направлення позивачу скарги не вплинуло на законність наказу Мін'юсту. Право вибору стягнення за порушення порядку державної реєстра- 
ції належить Мін'юсту, йому ж надано повноваження самостійно визначати строк тимчасового блокування. Вибраний відповідачем вид відповідальності у вигляді тимчасового блокування доступу до Державного реєстру прав $€$ найменш суворішим із можливих видів відповідальності. Такий вид відповідальності визнаний судом співмірним iз учиненим позивачем порушенням, що призвело до скасування реєстраційної дії внаслідок порушення прав третьої особи [19].

На підставі проведеного дослідження слід зробити такі висновки:

1. Справа про скасування наказу Мін'юсту щодо скарг у сфері державної реєстрації речових прав залежно від суб'єктного складу сторін належить до цивільної або господарської юрисдикції, якщо порушення своїх прав позивач убачає в наслідках рішення Мін'юсту та (або) державного реєстратора, які він уважає неправомірними, а ці наслідки призвели до виникнення, зміни чи припинення цивільних правовідносин, зокрема пов'язаних із реалізацією його майнових інтересів.

2. Участь Мін'юсту та державного реєстратора як співвідповідачів у справі, в якій оскарження наказу Мін'юсту використовується для вирішення спору щодо речового права з іншою особою (навіть якщо остання має в справі статус третьої особи), не змінює приватноправовий характер спору та не зумовлює його належність до адміністративної юрисдикції.

3. Якщо спір стосується виключно проведення державної реєстрації речового права, а не законності фактів, що були підставою для вчинення реєстраційних дій, то він не є спором про право, а має публічно-правовий характер, оскільки виник унаслідок виконання відповідачем владних управлінських функцій, і підлягає розгляду за правилами адміністративного судочинства. У такому разі об'єднання в позовній заяві вимог про поновлення реєстраційних записів і скасування наказу Мін'юсту не виключає адміністратив- ної юрисдикції спору, тому що перша вимога не може розглядатися окремо від вимоги про скасування наказу Мін'юсту й є наслідком визнання незаконним і скасування такого наказу.

Проте не належить до адміністративної юрисдикції спір, в якому необхідно дати правову оцінку правомірності як оскаржуваного наказу Мін'юсту (на предмет дотримання процедури його прийняття), так і правомірності набуття права на нерухоме майно та відповідних реєстраційних дій (на предмет їх відповідності нормам матеріального права).

4. Справи за позовами державних реєстраторів щодо скасування наказів Мін'юсту належать до адміністративної юрисдикції.

у статті досліджено питання судової юрисдикиї справ про скасування наказів Мін'юсту щодо скарг у сфері державної реєстрації речових прав на нерухоме майно. Проаналізовано правові позииії Верховного Суду щодо зазначеного питання та конкретизовано обставини, що визначають приналежність зазначених справ до циивільної, господарської $i$ адміністративної юрисдикиії.

Установлено, що участь Мін'юсmy ma державного реєстратора як співвідповідача у справі, в якій оскаржується наказ Мін'юсту, не e достатньою ознакою адміністративної юрисдикції. Якщзо відповідний позов подано для вирішення спору з іншою особою щодо речового права, то участь ицих суб’єктів публічного права не змінюе приватноправовий характер спору. Належним відповідачем у такій справі є особа, право на майно якої оспорюеться.

Не належить до адміністративної юрисдикиї спір, в якому необхідно надати правову оиінку правомірності як оскаржуваного наказу Мін'юсту, так і набуття права на нерухоме майно та відповідних реєстраційних дій. Якщо порушення своїх прав позивач убачає у наслідках рішення 
Мін'юсту ma (або) державного реєстратора, які він уважає неправомірними, а изі наслідки призвели до виникнення, зміни чи припинення изивільних правовідносин, то визнання таких рішень незаконними є способом захисту иивільних прав та інтересів, а справа належить залежно від суб'єктного складу до иивільної або господарської юрисдикціï.

Якщо спір стосується виключно здійснення державної реєстраціi речового права, ане законності фактів, шьо були підставою для вчинення реєстраційних дій, то він не є спором про право та підлягає розгляду за правилами адміністративного судочинства. У такому разі об’єднання в позовній заяві вимог про поновлення реєстраційних записів $i$ скасування наказу Мін'юсту не виключае адміністративної юрисдикиіï спору, оскільки поновлення реєстраційних записів є наслідком визнання незаконним і скасування такого наказу.

Справи за позовами державних реєстраторів щодо скасування наказів Мін'юсту (зокрема, щзодо застосованої до позивача санкцї за допущені порушення) належать до адміністративної юрисдикції.

Ключові слова: судова юрисдикція, речові права, нерухоме майно, державна реєстрація речового права, державний реєстратор.

Antoniuk O. Jurisdiction of cases on cancellation of orders of the Ministry of Justice of Ukraine on complaints in the field of state registration of property rights

The article examines the issue of court's jurisdiction of cases on revocation of orders of the Ministry of Justice on complaints in the field of state registration of real property rights. The legal positions of the Supreme Court on the mentioned issue were analyzed and the circumstances that determine the affiliation of the mentioned cases to civil, commercial and administrative jurisdiction were specified.
It has been defined that the involvement of the Ministry of Justice and the state registrar as co-defendants in a case revocating an order of the Ministry of Justice is not a sufficient characteristic of administrative jurisdiction. If the relevant claim is filed to resolve a dispute with another person over property right, the participation of these subjects of public law does not change the private nature of the dispute. The proper defendant in such a case is the person whose right to property is disputed.

A dispute in which it is necessary to provide a legal assessment of the legitimacy of both the disputed order of the Ministry of Justice and the acquisition of the right to real estate and the relevant registration actions does not belong to the administrative jurisdiction. If the plaintiff perceives the violation of his rights in the consequences of the decision of the Ministry of Justice and (or) the state registrar, which he considers illegal, and these consequences led to the emergence, change or termination of civil relations, then recognizing such decisions illegal is a way to protect civil rights and interests, and the case belongs, depending on the subject composition, to civil or commercial jurisdiction.

If the dispute concerns only the implementation of the state registration of property right, and not the legitimacy of the facts that were the basis for registration actions, it is not a dispute about the right and is a subject of proceeding under the rules of administrative procedure. In this case, joining in the statement of claim the requirements for renewal of registration records and cancellation of the order of the Ministry of Justice does not exclude the administrative jurisdiction of the dispute, as renewal of records is a consequence of declaring illegal and cancellation of such order.

Cases of state registrars' claims for revocation of orders of the Ministry of Justice (in particular, regarding the 
sanction applied to the plaintiff for violations) belong to the administrative jurisdiction.

Key words: court's jurisdiction, property rights, real estate, state registration of property right, state registrar.

\section{Література}

1. Постанова Великої Палати ВС від 04 вересня 2018 року у справі № 823/2042 / 16. URL : http: / / reyestr.court.gov.ua/Review / 77969515

2. Постанова Великої Палати ВC від 27 листопада 2019 року у справі № 815/1915/18. URL : http: // reyestr. court.gov.ua/Review/86333852.

3. Постанова ВС від 26 квітня 2019 року у справі № 821/669/17. URL : http:// reyestr.court.gov.ua/Review/81479568.

4. Постанова Великої Палати ВС віо 11 квітня 2018 року у справі № 910/8424 / 17. URL : http:// reyestr.court.gov.ua/Review/ 73408853 .

5. Постанова ВС від 06 червня 2018 року y справі № 804/2296/17. URL : http:// reyestr.court.gov.ua / Review / 74616617 .

6. Постанова ВС від 06 липня 2018 року у справі № 826/3442/17. URL : http:// reyestr.court.gov.ua/Review/75175189.

7. Постанова ВС від 13 вересня 2019 року у справі № 802/1211/17-a. URL : http:// reyestr.court.gov.ua/Review/84229358.

8. Постанова Великої Палати ВС віо 29 травня 2019 року у справі № 826 / 9341 / 17. URL : http:// reyestr.court.gov.ua/Review/ 82420792
9. Постанова ВС від 03 березня 2020 року y справі № 826/6166/17. URL : http:// reyestr.court.gov.ua / Review/87963294.

10. Постанова Великої Палати ВС від 30 січня 2020 року у справі № 826/5968/ 17. URL : http: / / reyestr.court.gov.ua/Review / 87454065 .

11. Постанова ВС від 30 січня 2020 року у справі № 826/5364/18. URL : http:// reyestr.court.gov.ua/Review/87268954.

12. Постанова ВС від 17 жовтня 2019 року у справі № 826/13993/17. URL : http:// reyestr.court.gov.ua/Review/ 85032169 .

13. Постанова ВС від 05 грудня 2019 року y cправi № 826/19534/16. URL : http:/ / reyestr.court.gov.ua/Review/86162235.

14. Постанова Великої Палати ВС від 04 лютого 2020 року у справі № 910 / 7781 / 19. URL : http:// reyestr.court.gov.ua/Review/ 87517577

15. Постанова Великої Палати ВC від 12 лютого 2020 року у справі № 1840 / 3241 / 18. URL : http:// reyestr.court.gov.ua/Review / 87733275 .

16. Постанова ВС віа 05 березня 2020 року у справі № 815/1446/18. URL : http:// reyestr.court.gov.ua/Review / 88027683 .

17. Постанова ВС від 29 квітня 2020 року y cправi № 2040/8209/18. URL : http:// reyestr.court.gov.ua/Review/89013202.

18. Постанова ВС від 07 травня 2020 року у справі № 819/1499/17. URL : http:// reyestr.court.gov.ua/Review/89112071.

19. Постанова ВС від 29 квітня 2020 року y справi № 826/15358/17. URL: http:// reyestr.court.gov.ua/Review/88986357. 